\title{
Anatomical Study of Six Ocimum Species: The Valuable Method Used in Indian Systems of Medicines (ISM)
}

\author{
Research Article
}

\section{Sagarika Parida1*, Bikram Keshari Mohapatra1, Gyanranjan Mahalik1}

1. Department of Botany, School of Applied Sciences,

Centurion University of Technology and Management, Odisha, India

\begin{abstract}
This study aimed to characterize the morphological and anatomical traits of six Ocimum species namely Ocimum tenuiflorum L. Syn. O. Sanctum L. (green var. known as Radha Tulasi), O. tenuiflorum L. (purple var. known as Krishna Tulasi), O. basilicum L.( green var. known as Sugandhi Tulasi), O. basilicum var. pupurascens L. ( purple var. known as Durlabha Tulasi), O. canum Sims. (Kanaka Tulasi) and O. gratissimum L. (Rama Tulasi). Chlorophyll estimation of young and matured leaves was also estimated. Cholorophyll a, Chl. b and total chlorophyll was maximum in both young and matured leaves of $O$. gratissimum L. compared to other species. Carotenoid pigments was maximum of $203.94 \mathrm{mg} / \mathrm{ml}$ in young leaves of $O$. gratissimum L. and $244.92 \mathrm{mg} / \mathrm{ml}$ in matured leaves of $O$. sanctum L. Comparative morphological characters and anatomical variation were studied for identification of the desired species in drug manufacturing industries before making formulations. This study will certainly help to ensure the quality of the crude drug as these are collected by untrained workers and supplied in dry condition to the drug manufacturing industries. Therefore, there is a chance of adulteration because of vested interest or ignorance as many plants are known by common names or in vernacular names. It was found that the six species can be identified and authenticated using these experimental findings before preparation of compound Ayurveda, Siddha and Unani (ASU) drugs in Indian System of Medicines.
\end{abstract}

Key Words: Adulteration, Anatomical identification, Chlorophyll estimation, Ocimum spp., Indian Systems of Medicine.

\section{Introduction}

Medicinal plants play an important role in the health of individuals and human beings. The Indian System of Medicine is the culmination of Indian thought of medicine for healthy living. It is combined with other system of medicine like Greece (resulting in Unani Medicine) or Germany (Homeopathy) or our scriptures/sages which gave us the science of Ayurveda, Siddha and also Yoga and Naturopathy for successful management of various disease conditions. The medicinal properties of these plants are based on bioactive constituents that produce a particular action on human body. Therefore, plant remains to be the major source of medicine from the ancient time. Among the medicinal plants, Ocimum is the important genus of the subfamily Nepetoideae under the family Lamiaceae. The word is derived from the Greek word "Ozo" meaning "smell" and is called as king of herbs due to its use in traditional systems of medicine $(1,2)$. It has been reported that genus Ocimum has more than 160 species

\section{* Corresponding Author:}

\section{Sagarika Parida}

Department of Botany, School of Applied Sciences, Centurion University of Technology and Management, Odisha, India.

Email Id: sagarika.parida@,cutm.ac.in and is the largest genera of which 65 species are native to Ocimum and the remaining should be considered as synonyms (3). In India, about nine species of Ocimum have been reported including three exotic species namely, $O$. americanum L., $O$. minimum L. and $O$. X africanum Lour. (4). Different Ocimum species exhibit variation in physical appearance, chemical composition and therefore all the species possess different pharmacological activities. Botanical, pharmacological, phytochemical, ethnomedicinal and toxicological informations were collected and reviewed on O.sanctum L. (5).

The present study was conducted with the aim of identifying six different species of Ocimum based on anatomical differences before using for making the formulations in drug industries. Besides this chlorophyll $\mathrm{a}$, chlorophyll $\mathrm{b}$, total chlorophyll and carotenoids were also evaluated in these six species. Ocimum species show wide morphological variations, growth attributes, reproductive behavior including variations in chemical composition in relation with environmental factors (6) because of genetic variations in their inter and intra specific variability. Advancement in classification of Ocimum was introduced $(7,8)$ based on essential oil compositions from the aerial parts. Chemotaxonomy can be used to differentiate the genotypes of the same species. As it generates confusions because of variation in chemical composition due to environmental influence, therefore anatomical evaluation and 
Sagarika Parida et.al., Anatomical Study of Six Ocimum Species: The Valuable Method Used in Indian Systems of Medicines

authentication of desired species is the easiest and cost effective method for proper identification before making the formulations in drug industries. There is confusion in vernacular name, as the plant parts or the whole plant is collected by unskilled labour and from them the crude drug is procured by the drug industries, therefore this plant parts should be examined anatomically. In this study six Ocimum species are differentiated based on morpho-chemical-anatomical characterization.

\section{Materials and Methods}

\section{Collection of Samples}

The fresh plants were collected from medicinal plant garden of Centurion University of Technology and Management, Bhubaneswar Campus, Odisha which is located in 20.1756 degree $\mathrm{N}$ latitude and 85.7066 degree E longitude during the month of February and March. These plant species were identified with the literature data available in the department of Botany. In the present study six Ocimum species namely Ocimum tenuiflorum L. Syn. O. Sanctum L. (green var. known as Radha Tulasi), O. tenuiflorum L. (purple var. known as Krishna Tulasi), O. basilicum L.( green var. known as Sugandhi), O. basilicum var. pupurascens L.( purple var. known as Durlabha), O. canum Sims. (Kanaka Tulasi) and $O$. gratissimum L. (Rama Tulasi) were taken for morphological study (Fig.1-6), anatomical study of stem and chlorophyll estimation of young and matured leaves. Among these two varieties from Ocimum tenuiflorum L., two varieties of $O$. basilicum L. and one variety from $O$. canum Sims. and one from $O$. gratissimum L. were taken for this study (Table 1).

Table 1. Ocimum species with common and regional names

\begin{tabular}{|c|c|c|c|}
\hline $\begin{array}{l}\text { Sl. } \\
\text { N } \\
\text { o. }\end{array}$ & Ocimum species & $\begin{array}{l}\text { Common } \\
\text { Name }\end{array}$ & $\begin{array}{l}\text { Odia } \\
\text { Name }\end{array}$ \\
\hline 1 & $\begin{array}{l}\text { Ocimum tenuiflorum } \\
\text { L. Syn. O. sanctum } \\
\text { L. (green variety) }\end{array}$ & $\begin{array}{l}\text { Sacred } \\
\text { basil/holy } \\
\text { basil }\end{array}$ & $\begin{array}{l}\text { Radha } \\
\text { Tulasi }\end{array}$ \\
\hline 2 & $\begin{array}{l}\text { O. tenuiflorum L. } \\
\text { Syn. O. sanctum L. } \\
\text { (purple variety) }\end{array}$ & $\begin{array}{l}\text { Sacred } \\
\text { basil/holy } \\
\text { basil }\end{array}$ & $\begin{array}{l}\text { Krishna } \\
\text { Tulasi }\end{array}$ \\
\hline 3 & $\begin{array}{l}\text { O. basilicum L. } \\
\text { (green variety) }\end{array}$ & $\begin{array}{l}\text { Sweet } \\
\text { basil }\end{array}$ & $\begin{array}{l}\text { Sugandhi } \\
\text { Tulasi/ } \\
\text { Babu } \\
\text { Tulasi / } \\
\text { Dahana } \\
\text { Tulasi }\end{array}$ \\
\hline 4 & $\begin{array}{l}\text { O. basilicum var. } \\
\text { pupurascens L. } \\
\text { (purple variety) }\end{array}$ & $\begin{array}{l}\text { Purple } \\
\text { basil/Red } \\
\text { Rubin } \\
\text { basil }\end{array}$ & $\begin{array}{l}\text { Durlabha } \\
\text { Tulasi/ } \\
\text { Marua } \\
\text { Tulasi }\end{array}$ \\
\hline
\end{tabular}

\begin{tabular}{|l|l|l|l|}
\hline 5 & O. canum Sims. & $\begin{array}{l}\text { Hoary } \\
\text { basil/Wild } \\
\text { basil }\end{array}$ & $\begin{array}{l}\text { Kanaka } \\
\text { Tulasi/ } \\
\text { Landa } \\
\text { baguli }\end{array}$ \\
\hline 6 & O. gratissimum L. & $\begin{array}{l}\text { Rama } \\
\text { Tulasi// } \\
\text { Basil/ } \\
\text { African } \\
\text { basil }\end{array}$ & $\begin{array}{l}\text { Bana } \\
\text { Tulasi/ } \\
\text { Ghoda } \\
\text { Tulasi/ } \\
\text { Gandha } \\
\text { Tulasi }\end{array}$ \\
\hline
\end{tabular}

\section{Anatomical Study}

The experiment was conducted in the experimental laboratory of Botany Department of Centurion University of technology and management, Bhubaneswar Campus, Odisha. Stems of these species were washed thoroughly with tap water. Uniformly dissected fine, thin transverse hand sections were selected for each species separately, stained with safranin-O and observed under compound microscope.

\section{Chlorophyll Estimation}

Finely cut fresh leaves of $0.5 \mathrm{mg}$ of Ocimum spp. was taken separately and grinded by motor pestle with approximately $10 \mathrm{ml}$ of $80 \%$ acetone. It was then centrifuged at $10,000 \mathrm{rpm}$ for 10 minutes at $4^{\circ} \mathrm{C}$. The supernatant was collected and absorbance at $470 \mathrm{~nm}$, $646.8 \mathrm{~nm}$, and at $663.2 \mathrm{~nm}$. was recorded using UVvisible spectrophotometer for each species separately. The concentrations of chlorophyll a, chlorophyll $b$, total chlorophyll and carotenoids were calculated using the following equation (9).

- Chlorophyll a $(\mathrm{mg} / \mathrm{ml})=12.25 \quad(\mathrm{~A} 663.2 \mathrm{~nm})-2.79$ (A646.8nm)

- Chlorophyll b (mg/ml) =21.50 (A646.8nm)-5.10 (A663.2nm)

- Total chlorophyll $[(\mathrm{a}+\mathrm{b}) \mathrm{mg} / \mathrm{ml}]=7.15(\mathrm{~A} 663.2 \mathrm{~nm})$ +18.71 (A646.8nm)

- Carotenoids $=[100(\mathrm{~A} 470 \mathrm{~nm})-(1.82 \mathrm{chla}+85.02 \mathrm{chlb})] /$ 198

\section{Results and Discussion}

\section{Morphological Characterestics}

Morphological studies of six Ocimum species showed a high level of variability (Fig. 1-6). For identification of six species of Ocimum, morphological attributes like leaf shape, colour, leaf apex, stem, inflorescence, flower and seed were taken in to consideration (Table 2) as they play the major role (10). These results coincided with the literature data carried on four species of Ocimum (11). 
International Journal of Ayurvedic Medicine, Vol 11 (2), 278-283

\section{Sl. No. Ocimum Taxa}

1 O. canum Sims.

$2 \quad$ Ocimum tenuiflorum $\mathrm{L}$. Syn. O. sanctum

$3 \quad$ L. (green variety)

3 O. tenuiflorum L. Syn. O. sanctum

4 L. (purple variety)

$5 \quad$ O. basilicum var. pupurascens L. (purple variety)

6 O. basilicum L. (green variety)

\section{Table 2. Morphological Characterestics of six Ocimum Taxa}

\section{Morphological characters}

Leaf ovate, obovate, hairy, inflorescence greenish in colour, flower white to whitish gray, calyx is green in colour and two upper calyx lobes are pubescent, seeds globose and dark brown in colour

Leaf ovate, obovate, elliptic- oblong and hairy, obtuse to acute at apex, inflorescence verticillaster, green in colour, flower white, calyx green, pubescent, seeds globose, brown in colour

Leaf ovate, obovate, elliptic- oblong and hairy, obtuse to acute at apex, inflorescence purple in colour, flower purple, calyx purple, pubescent, globose seeds, brown in colour

Leaf petiolate, ovate, obovate, elliptic-lanceolate, acute or slightly acuminate at apex, distinctly serrate along margins, glabrous except hairy mid rib, inflorescence greenish in colour, flower yellowish white, calyx green, pubescent, seeds subglobose, brown

Leaf elliptic-lanceolate, leaf apex, stems with sparse hairy, inflorescence greenish in colour, flower pinkish white, calyx greenish purple and some cases purple, ellipsoid seeds, black in colour

Leaf ovate-lanceolate to oblong- lanceolate, acute leaf apex, leaf lamina glabrous, vein-lets hairy, inflorescence greenish in colour, flower whitish pink, calyx light green, hairy, brownish black ellipsoid seeds

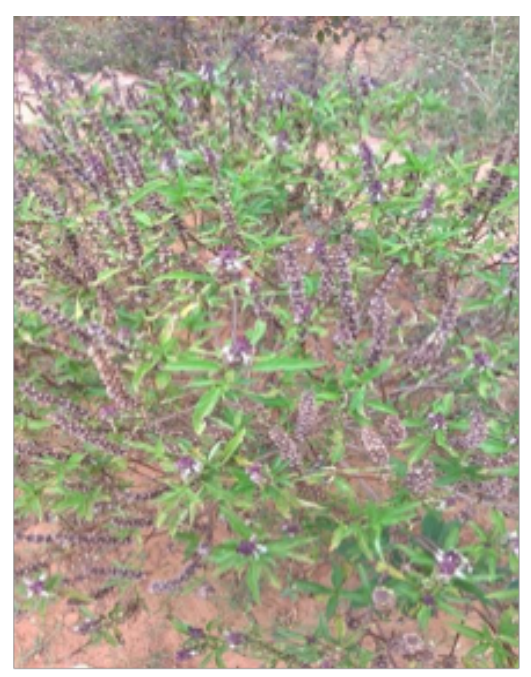

Fig. 1. Ocimum canum (Kanaka Tulasi)

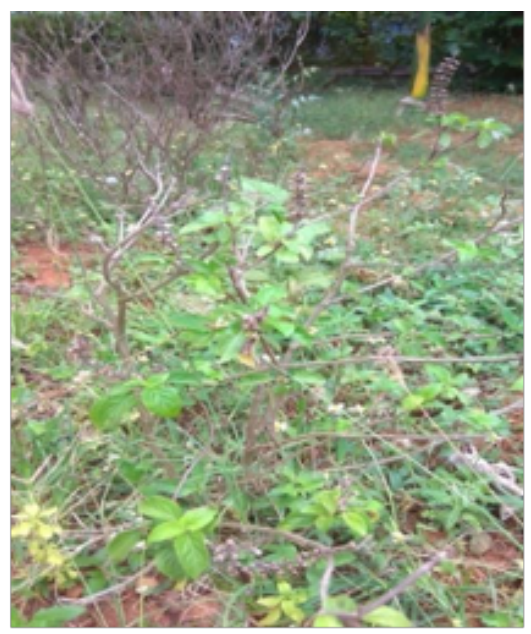

Fig. 4. O. gratissimum L. (Rama Tulasi)

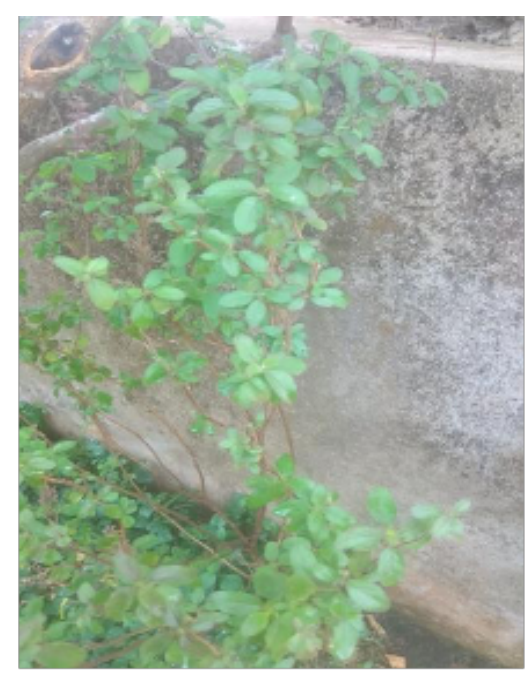

Fig. 2. O. sanctum (Radha Tulasi)

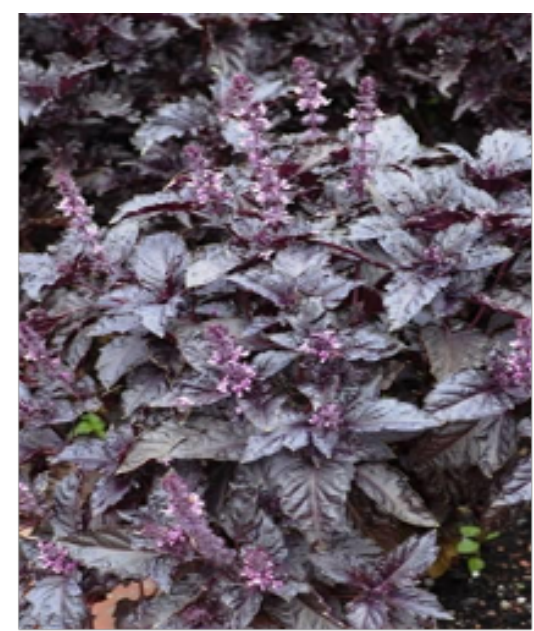

Fig. 5. $O$. basilicum var. purpurascens $\mathrm{L}$ (Durlabha Tulasi)

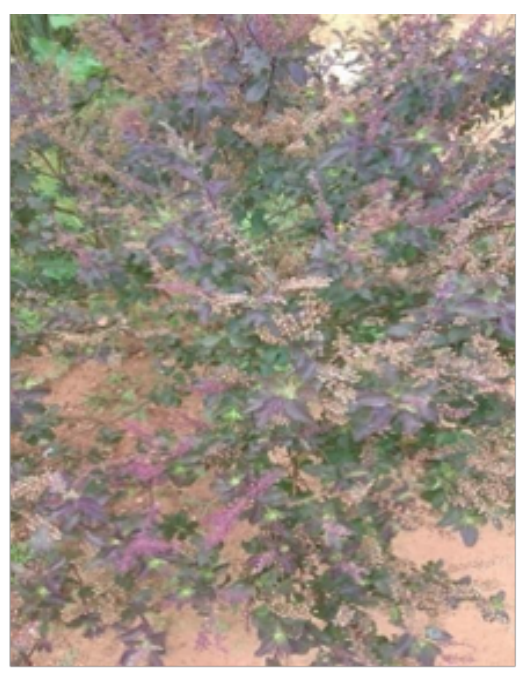

Fig. 3. O. sanctum (Krishna Tulasi)

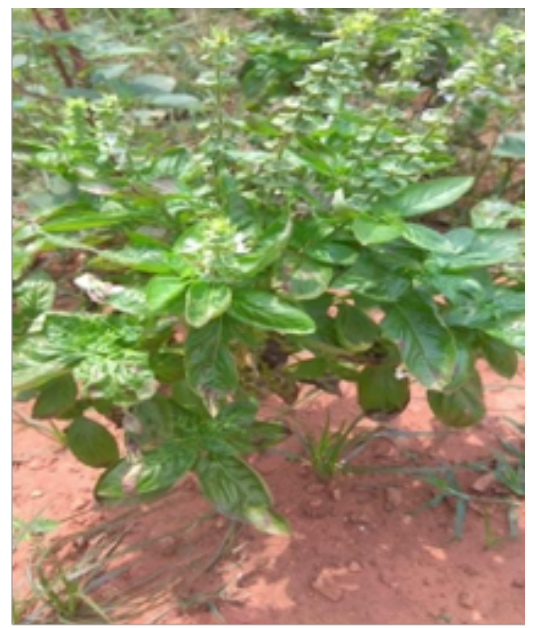

Fig. 6. O. basilicum $\mathrm{L}$.

(Sungadhi Tulasi) 


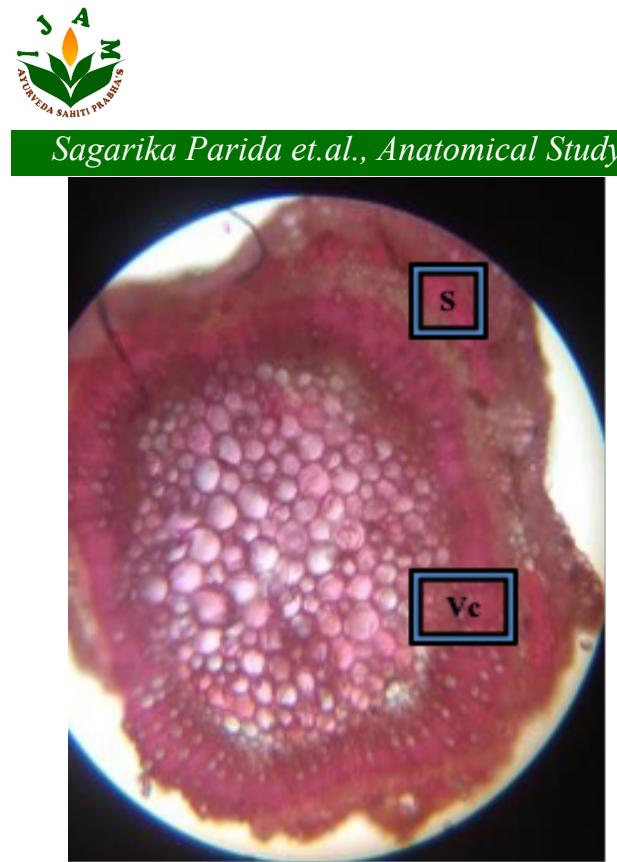

Fig. 7. Ocimum canum (Kanaka Tulasi)

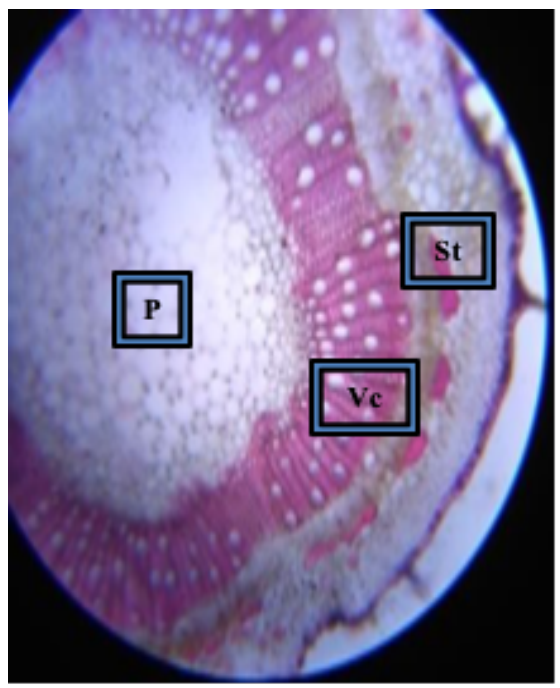

Fig. 10. O. gratissimum L. (Rama Tulasi)

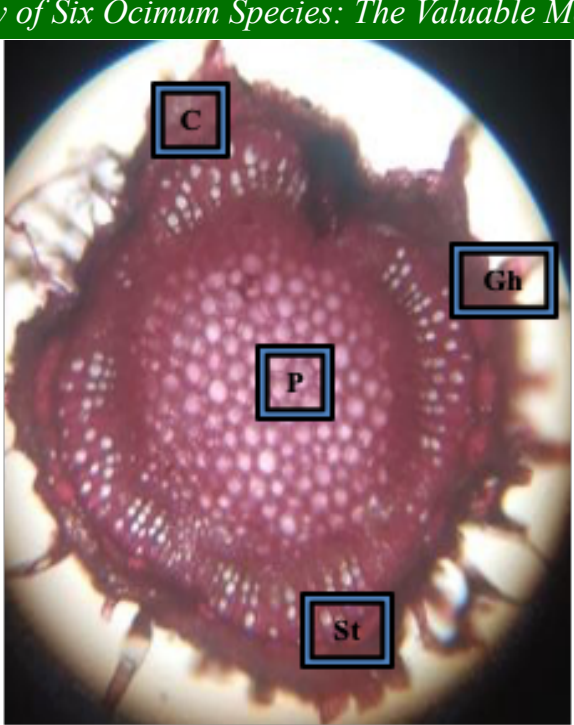

Fig. 8. O. sanctum (Radha Tulasi)

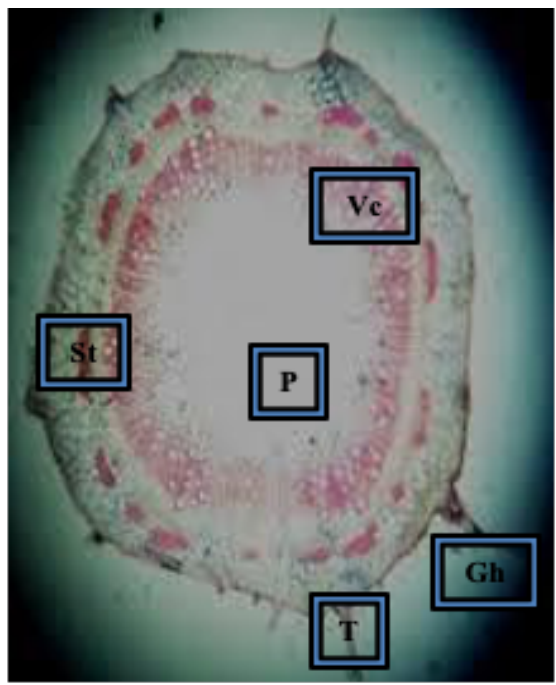

Fig. 11. $O$. basilicum var. purpurascens $\mathrm{L}$ (Durlabha Tulasi)

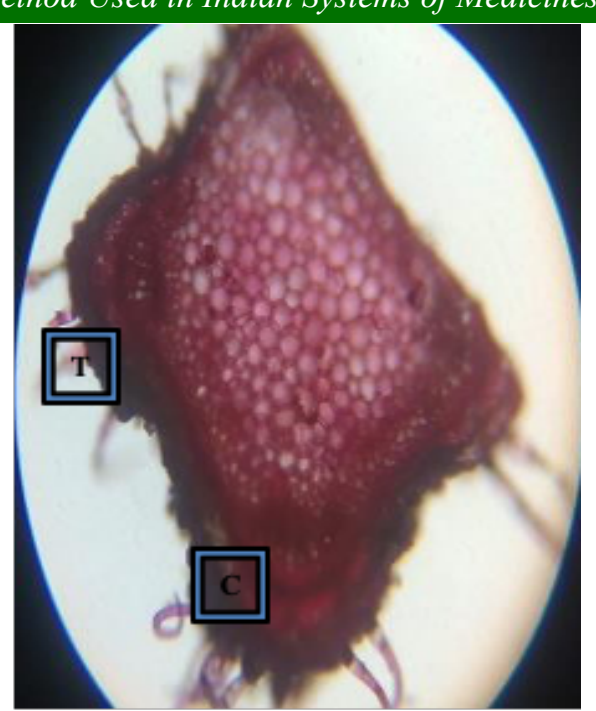

Fig. 9. O. sanctum (Krishna Tulasi)

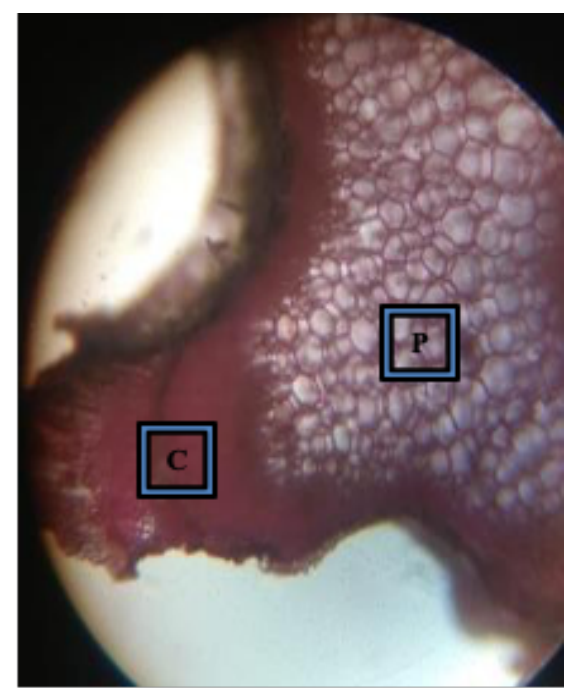

Fig. 12. O. basilicum $\mathrm{L}$.

(Sungadhi Tulasi)

( ${ }^{*}$ : Collenchyma; Gh: Glandular hairs; P: Parenchyma; S: Sclerenchyma; St: Stone cells; T: Trichomes; Vc: Vascular cylinder)

\section{Anatomical Characteristics}

\section{Ocimum canum L. (Kanaka Tulasi)}

The transverse section of stem showed rectangular in shape with four ridges and grooves. The epidermis layer is uni-seriate, and has been covered by a thin cuticle layer. The parenchymatous cortex is collenchymatic in a hypodermal position. The patches of stone cells were mostly found to confine to four ridges. Very few stone cells were noticed in the shallow portion of the stem. The large bundles have radial ranges of ligneous vessels separated by uni- or multi-seriate areas of parenchymatous cells. Four large vascular bundles were also observed at each corner. The number of glandular and tectorial trichomes were very few. The tectorial trichomes are uniseriate, consisting of three cells, with an acute apex and a bi-or multicellular basis (Fig. 7).

\section{O. tenuiflorum L. (Radha Tulasi)}

Transverse section of $O$. sanctum (Radha Tulasi) is rectangular in outline with well developed four ridges in four corners of the stem. Number of trichomes and glandular hairs are present covering the entire surface of the stem. The epidermis is composed of a thin cuticle covering externally. Collenchymatous tissue is located under the epidermis just below the ridges. The cortex consists of parenchymatous cells with air spaces. Small groups of stone cells were arranged ring like layer in the peripheral cortical region with more patches of stone cells in less developed ridges. Vascular bundles are conjoint, collateral and endarch type. Endodermis is conspicuous. Vascular bundles are more prominent in four corners. The cambium activity produces phloem to the exterior and xylem to the interior. Ray parenchyma located in between the vascular bundles. Pith is composed of polygonal, oval and spherical parenchymatous cells with small intercellular spaces (Fig. 8.).

\section{O. tenuiflorum L. (Krishna Tulasi)}

Transverse section of $O$. sanctum L. is rectangular in outline with four well developed ridges in four corners. Trichomes are mostly confined to the four corners and very few trichomes are present in the furrows. The epidermis is composed of a thin cuticle 
covering externally. Collenchyma tissue is located under the epidermis, patches of collenchymatous cells were found to be confined to the corners. The cortex consists of parenchymatous cells with air spaces. Vascular bundles are conjoint, collateral and endarch type. Endodermis is conspicuous. Vascular bundles are more prominent in four corners. Ray parenchyma located in between the vascular bundles. Pith is composed of polygonal, oval and spherical parenchymatous cells with small intercellular spaces (Fig. 9.).

\section{O. gratissimum L. (Rama Tulasi)}

The cross section of is nearly quadrangular in outline (Fig. 10) and divided in to two parts; the bark and the central cylinder. The bark is thin, has three primary tissues (epidermis, cortical parenchyma and collenchyma). The epidermis is consists of a single base of small contiguous rectangular cells, the wall is thin. The cortical parenchyma consists of several layers of polygonal cells with thin walls. Group of stone cells are present just below the collenchymatous mass of cells below the less developed ridges. Very few stone cells are also observed in furrows. Sclerenchymatous tissue surrounds the phloem at each corners of stem. Few trichomes especially glandular trichomes are present. The central cylinder is more developed than the bark. The primary wood, secondary phloem and secondary wood are arranged in radial alignment. The pith is occupied by parenchymatous cells and constitutes large polygonal cells (Fig. 10).

\section{O. basilicum var.purpurascens L. (Durlabha Tulasi)}

The transverse section showed epidermis with very few trichomes. The cortex consists parenchymatous tissue with air spaces. Patches of stone cells are present in the cortical region surrounding the peripheral region of the central vascular cylinder (Fig.11). Vascular bundles are conjoint, collateral and endarch type. Endodermis is conspicuous. The cambium activity produces phloem to the exterior and xylem to the interior. Ray parenchyma located in between the vascular bundles. Pith is composed of polygonal, oval and spherical parenchymatous cells with small intercellular spaces.

\section{O. basilicum L. (Sugandhi Tulasi)}

The epidermis is single layered without trichomes on the surface of stem. More pronounced collenchyma tissue is located in four ridges. The cortex consists of parenchymatous tissue with air spaces. Vascular bundles are conjoint, collateral and endarch type. Endodermis is conspicuous. The cambium activity produces phloem to the exterior and xylem to the interior. Ray parenchyma located in between the vascular bundles. Pith is composed of polygonal, oval and spherical parenchymatous cells with small intercellular spaces (Fig. 12). Phylogenetic evolution study was conducted and correlation was made on a number of varieties of genus Ocimum. Different morphological variations were also studied (12).

\section{Chlorophyll Estimation}

Chlorophyll a, b, total chlorophyll and carotenoids of both young and matured leaves of six species of Ocimum were estimated and presented in Table 3 . It was revealed that total chlorophyll content in matured leaf of $O$. sanctum L. (Radha Tulasi or Green Tulasi) was maximum of $36.79 \mathrm{mg} / \mathrm{ml}$ whereas least amount of $12.65 \mathrm{mg} / \mathrm{ml}$ of Chl-a was recorded in young leaf. Maximum of $126.1 \mathrm{mg} / \mathrm{ml}$ carotenoid was estimated in matured leaf.

Data depicted in Table 3, revealed that Chl.a was found to be maximum of $19.18 \mathrm{mg} / \mathrm{ml}$ in matured leaves of $O$. basilicum L. (Purple) followed by 19.04, 18.77, $18.18,17.67$ and $13.83 \mathrm{mg} / \mathrm{ml}$ in $O$. gratissimum L., $O$. sanctum L. (Purple), O. canum L., O. basilicum L. (Green) and $O$. sanctum L. (Green) respectively. Chl-b was estimated with $32.85 \mathrm{mg} / \mathrm{ml}$ in matured leaves of $O$. gratissimum L. followed by $28.15 \mathrm{mg} / \mathrm{ml}$ in O. basilicum L. (Purple), $23.28 \mathrm{mg} / \mathrm{ml}$ in O. sanctum L. (Purple), 22.95 $\mathrm{mg} / \mathrm{ml}$ in $O$. sanctum L. (Green) and $20.72 \mathrm{mg} / \mathrm{ml}$ in $O$. canumL. Least Chl.a of $18.34 \mathrm{mg} / \mathrm{ml} \mathrm{chl} \mathrm{b}$ was reported in $O$. basilicum L. (Green). It was also observed that total chlorophyll content in matured leaves of $O$. gratissimum L.(Rama Tulasi) was maximum of $51.89 \mathrm{mg} / \mathrm{ml}$ followed by $47.34 \mathrm{mg} / \mathrm{ml}$ in $O$. basilicum L. (Purple), $42.05 \mathrm{mg} / \mathrm{ml}$ young leaf with $44.05 \mathrm{mg} / \mathrm{ml}$ whereas the amount of Chl.a of $17.01 \mathrm{mg} / \mathrm{ml}$ and $19.04 \mathrm{mg} / \mathrm{ml}$ in $O$. sanctum L. (Purple), O. canum L. with 38.91, O. sanctum L. (Green) with $36.79 \mathrm{mg} / \mathrm{ml}$ and $O$. basilicum L. (Green) with 36.02 $\mathrm{mg} / \mathrm{ml}$ respectively. Maximum of $244.92 \mathrm{mg} / \mathrm{ml}$ carotenoid was estimated to be present in matured leaf of $O$. sanctum L. (Purple) followed by 237.45, 230.56, $129.71,126.1$ and $121.60 \mathrm{mg} / \mathrm{ml}$ in $O$. gratissimum L., $O$. basilicum L. (Purple), O. canum L., O. sanctum L. (Green), and $O$. basilicum L. (Green) respectively. It was also revealed that in all cases the young leaves contain less quantity of chlorophyll a, chlorophyll b, and total chlorophyll and carotenoid pigments in comparison to matured leaves that indicates the efficiency of matured leaves for increasing drug efficacy.

Table 3.Pigment Estimation in Ocimum species

Ocimum spp.

Pigments (mg/ml)

\begin{tabular}{|c|c|c|c|c|c|c|c|c|}
\hline & \multirow{2}{*}{\multicolumn{2}{|c|}{ Chl. a }} & \multirow{2}{*}{\multicolumn{2}{|c|}{ Chl. b }} & \multirow{2}{*}{\multicolumn{2}{|c|}{ Total Chl }} & \multirow{2}{*}{\multicolumn{2}{|c|}{ Carotenoid }} \\
\hline & & & & & & & & \\
\hline & $\begin{array}{l}\text { Young } \\
\text { leaves }\end{array}$ & $\begin{array}{c}\text { Matured } \\
\text { leaves }\end{array}$ & $\begin{array}{l}\text { Young } \\
\text { leaves }\end{array}$ & $\begin{array}{c}\text { Matured } \\
\text { leaves }\end{array}$ & $\begin{array}{l}\text { Young } \\
\text { leaves }\end{array}$ & $\begin{array}{c}\text { Matured } \\
\text { leaves }\end{array}$ & $\begin{array}{l}\text { Young } \\
\text { leaves }\end{array}$ & $\begin{array}{c}\text { Matured } \\
\text { leaves }\end{array}$ \\
\hline $\begin{array}{l}\text { O. basilicum L. } \\
\text { (Green) }\end{array}$ & 15.23 & 17.67 & 9.29 & 18.34 & 24.53 & 36.02 & 116.36 & 121.60 \\
\hline $\begin{array}{l}\text { O. basilicum L. } \\
\text { (Purple) }\end{array}$ & 9.07 & 19.18 & 10.49 & 28.15 & 19.57 & 47.34 & 93.28 & 230.56 \\
\hline O. canum $\mathrm{L}$. & 16.73 & 18.18 & 17.76 & 20.72 & 34.49 & 38.91 & 113.57 & 129.71 \\
\hline O. gratissimum $\mathrm{L}$. & 17.01 & 19.04 & 27.04 & 32.85 & 44.05 & 51.89 & 203.94 & 237.45 \\
\hline $\begin{array}{l}\text { O. sanctum } \mathrm{L} \text {. } \\
\text { (Green) }\end{array}$ & 12.65 & 13.83 & 21.27 & 22.95 & 33.92 & 36.79 & 118.51 & 126.1 \\
\hline O. sanctum $\mathrm{L}$. & 16.65 & 18.77 & 20.05 & 23.28 & 36.71 & 42.05 & 201.79 & 244.92 \\
\hline
\end{tabular}

(Purple) 
Literature data revealed the diversity of nine Ocimum genotypes based on morphological, chemical, RAPD identification and taxonomic classification (13). This indicated that for genotyping study RAPD technique is needed but for preparation of drug formulations, the anatomical study is a valuable and important easiest tool for identification of the raw drug before making the formulations. The morphological characteristics studies are the basic requirement for identification of plants but in drug manufacturing industry, anatomical study of dry collected raw materials should be checked as a quality control parameter. Data reported on four Ocimum species viz. O.basilicum var. thysiflora, $O$. sanctum. O. gratissimum and $O$. viride was reviewed and correlated with the present findings and proved to be useful in correct identification (14).

\section{Conclusion}

In this article the diversity of six Ocimum species was described in terms of morphological, anatomical and also based on chlorophyll content analyses. Based on the anatomical features it would be easier to distinguish six different Ocimum species from each other. All the species possess different pharmacological activities because of the huge variation in the chemical composition. This experiment helps to give the easiest methods to identify the species in crude dry form before preparation of formulations and is a valuable tool for authentication of the desired species. Morphological and anatomical characters play an important role in plant based crude drug identification and authentication and also helps to differentiate the species.

\section{Conflict of Interest}

None

\section{Acknowledgements}

The authors are thankful to Centurion University of Technology and Management for providing laboratory facilities to carry out this work.

\section{References}

1. Hereman S, Paxton's Botanical Dictionary. London; Bradbury Evans and Co. 1868

2. Simpson B. B, Corner O. M, Economic BotanyPlants in our World. McGraw-Hill Book Company, Hamburg 1986
3. Pushpangadan P, Bradu B. L, Chadha K. L , Gupta (Eds.) R, Advances in Horticulture, Malhotra Publishing House, New Delhi 1995

4. Balyan S. S, Pushpangadan P, A Study on the Taxonomic Status and Geographic Distribution of the Genus, Ocimum," PAFAI. 1988;10(2);13-19

5. Bano N, Ahmed A, Tanveer M, Khan G. M, Ansari M. T, Pharmacological Evaluation of Ocimum sanctum. Journal of Bioequivalence \& Bioavailability. 2017; 9(3); 387-392

6. Carovic K, Liber Z, Javornik B, Kolak I, Satovic Z, Genetic relationships within basil (Ocimum) as revealed by RADP and ALP markers. Acta Hort (ISHS) 2006; 760; 171-178

7. Lawrence B. M, Harley R. M, Reynolds (Eds.) $\mathrm{T}$, Advances in Labiateae Science, Royal Botanic Garden. Kew, UK; 1992; 399-436p

8. Grayer R. J , Kite G. C, Goldstone F. J , Bryan S. E, Paton A, Putievsky E, Infraspecific taxonomy and essential oil chemotypes in sweet basil, Ocimum basilicum. Phytochemistry. 1996; 43; 1033-1039

9. Aron D, Copper enzymes isolated chloroplasts, polyphenoloxidase in Beta vulgaris. Plant Physiology. 1949; 24; 1-15

10. Svecova E, Neujebauerov J, A study of 34 cultivars of basil (Ocimum L.) and their morpho- logical, economic and biochemical characteristics, using standardized descriptors. Acta Universitatis Sapientiae, Alimentaria. 2010; 3; 118-125

11. Rawat Rajni, Negi, K.S, Mehta P.S, Tiwari Vandana, Verma S.K and Bisht I.S; Study of six varieties of sweet basil (Ocimum basilicum L.) and their morphological variations: J. Non- Timber For Prodts. 2016, 23(1), 17-22

12. Mishra D, Awasthi A, Mishra P, Phylogenetic evolution studies on different varieties of genus Ocimum with special reference to Rewa district of Madhya Pradesh Sci Secure J Biotech. 2014; 3(2); 188-197

13. Tanmay Chowdhury, Amitava Mandal, Subhas Chandra Roy, Dillip Dey Serker, Diversity of the genus Ocimum (Lamiaceae) through morphomolecular (RAPD) and chemical (GC-MS) analysis. Journal of Genetic Engineering and Biotechnology. 2017; 15(1); 275-286

14. Rawat Rajni, Tiwari Vandana, Negi K.S; A comparative study of Morphological and Anatomical Structures of four Ocimum species in Uttarakhand, India, Journal of Drug Delivery \& Therapeutics. 2016; 6(6); 1-6. 